\title{
Myofibrillolysis and fibrosis predicts myocardial insufficiency
}

\author{
Jerzy Pacholewicz ${ }^{1}$, Michał Zakliczyński ${ }^{1}$, Jerzy Nożyński ${ }^{1}$, Paweł Nadziakiewicz ${ }^{2}$, Michał Zembala ${ }^{1}$, \\ Marian Zembala ${ }^{1}$
}

${ }^{1}$ Department of Cardiac, Vascular and Endovascular Surgery and Transplantology in Zabrze, Medical University of Silesia in Katowice, Silesian Center for Heart Diseases in Zabrze, Poland

${ }^{2}$ Department of Cardiac Anaesthesiology and Intensive Care, Silesian Medical University in Katowice, Silesian Center for Heart Diseases in Zabrze, Poland

Kardiochirurgia i Torakochirurgia Polska 2019; 16 (2): 57-64

\begin{abstract}
Introduction: Cardiocyte myofibrillolysis and interstitial fibrosis belong to histopathological changes in cardiomyopathies, leading to heart failure.

Aim: To evaluate these changes in apical resection during left ventricular assist device (LVAD) implantation.

Material and methods: The studied group consisted of 40 patients with cardiomyopathy, and apical samples excised during left ventricular assist device implantation were studied (CM/ VAD group, mean: $48.1 \pm 10 \mathrm{y} / \mathrm{o})$. A control group consisted of 6 apical samples from healthy heart graft donors (mean: $29 \pm 2.3$ years old). Area fraction (AF) was calculated for: fibrosis, cardiocytes with myofibrillolysis (MFL), non-myofibrillolytic cardiocytes (non-MFL).

Results: Single lymphocytes were seen in $18(45 \%)$ cases in the CM/VAD group. Cardiomyopathy grade evaluated semiquantitatively in CM/VAD was: slight ( $25 \%$ of a group), moderate (35.5\%), advanced (35.5\%). CM/VAD cases showed nearly ten times higher fibrosis than the control group. The MFL cells occupied nearly a five times larger area in CM/VAD than in the control group, whereas non-MFL cells were found in the control group, as a predominant pattern. The linear regression calculated between fibrosis AF and types of cardiocytes indicated the depletion of cardiomyocytes with fibrosis increase. The control group presented insignificant dependency between fibrosis and MFL cells, suggesting the lack of replacement fibrosis. Significant negative dependence between fibrosis and non-MFL cardiocytes suggested remodeling in controls. Correlation analysis showed a strong relation between depletion of normal cardiocytes and progression of fibrosis.

Conclusions: Progression of cardiomyopathy and fibrosis depends on the loss of cardiocytes rather than degeneration of these cells.
\end{abstract}

Key words: cardiomyopathy, sarcoplasm, myofibrillolysis.

\section{Streszczenie}

Wprowadzenie: Tkanka koniuszka lewej komory zawiera większą ilość mięśnia sercowego w porównaniu z materiałem z biopsji przegrody międzykomorowej, dlatego ma duże znaczenie diagnostyczne.

Cel: Określenie kluczowych zmian w niewydolnym sercu na podstawie analizy morfometrycznej.

Materiał i metody: Badana grupa składała się z 40 pacjentów z kardiomiopatią, którym wszczepiono urządzenie wspomagające pracę serca (grupa CM/VAD, średnia: 48,1 \pm 10 lat). Tkankę koniuszka lewej komory uzyskano podczas implantacji LVAD. Materiał kontrolny stanowiło 6 analogicznych fragmentów serca uzyskanych od osób po śmierci samobójczej (średnia: $29 \pm 2,3$ roku). Tkanki barwiono rutynowymi metodami (H\&E, Masson trichrome). Morfologię kardiomiocytów i nacieki zapalne oceniano pótilościowo. Frakcję pola powierzchni (AF) mierzono dla: tkanki włóknistej, kardiocytów z miofibrylolizą (MFL) i kardiocytów prawidłowych (non-MFL).

Wyniki: W grupie CM/VAD obecne były nieaktywne nacieki zapalne w 18 (45\%) przypadkach. We wszystkich przypadkach stwierdzono morfologię kardiomiopatyczną w nasileniu niewielkim (25\% grupy), umiarkowanym (35,5\%) lub ciężkim (35,5\%). W grupie CM/VAD obserwowano prawie $10-$ krotnie większe włóknienie niż w grupie kontrolnej. Kardiomiocyty miofibrylolityczne zajmowały prawie 5-krotnie większą AF niż w grupie kontrolnej. W grupie kontrolnej stwierdzono dominującą prawidłową sarkoplazmę, która zajmowała 2-krotnie większą AF powierzchni niż w grupie CM/VAD. Wyliczony stosunek powierzchni kardiocytów z miofibrylolizą do powierzchni prawidłowych kardiocytów wskazywał na dominację miofibrylolizy w grupie CM/VAD, podczas gdy w grupie kontrolnej obserwowano zjawisko odwrotne. W grupie CM/VAD stwierdzono postępujące zmniejszanie się obu typów kardiomiocytów wraz ze wzrostem zwłóknienia. W grupie kontrolnej stwierdzono nieistotną zależność między zwłóknieniem a kar-

Address for correspondence: Jerzy Pacholewicz MD, PhD, Department of Cardiac, Vascular and Endovascular Surgery and Transplantology, Medical University of Silesia, Silesian Center for Heart Diseases, 9 M. Skłodowskiej-Curie St, 41-800 Zabrze, Poland, phone: +48 3237338 57, e-mail: jerzypacholewicz@gmail.com Received: 16.05.2019, accepted: 7.06.2019. 
diocytami miofibrylolitycznymi, co wskazuje na brak aktywnego włóknienia pomartwiczego. Znamienna ujemna korelacja między włóknieniem a miofibrylolizą może świadczyć o przebudowie w grupie kontrolnej.

Wnioski: Włóknienie pomartwicze w kardiomiopatii jest ściśle i liniowo zależne od uszkodzenia kardiocytów.

Słowa kluczowe: kardiomiopatia, sarkoplazma, rozpad kardiomiocytów.

\section{Introduction}

Continuous flow left ventricular assist devices (CF-LVADs) have become a widely accepted treatment modality for advanced heart failure (HF) patients. The use of mechanical circulatory support LVAD as a bridge to transplant has been shown to improve the survival rate, functional status and quality of life of patients on the heart transplant waiting list. A necessity to excise a part of the left ventricle apex in order to place the inflow cannula of the pump creates the opportunity to perform the histopathological assessment of $\mathrm{HF}$ etiology. It should be pointed out that tissue harvested during LVAD implantation could play an essential diagnostic role, taking into consideration that it is more representative than the specimen obtained during a left ventricular biopsy because of tissue abundance, and more valuable when compared with classic endomyocardial samples achieved by the right ventricle access [1-3].

Table I. Population study of studied group

\begin{tabular}{lcc} 
Parameter & Results \\
Number of cases & 40 \\
\hline Observation time & $\begin{array}{c}2013-2016 \\
4 \text { years }\end{array}$ \\
\hline Age & $18-64$ \\
& & $48.1 \pm 0$ \\
\hline Sex & Male -40 \\
\hline Non-ischemic cardiomyopathy & & $28(70 \%)$ \\
\hline Ischemic cardiomyopathy & & $12(30 \%)$ \\
\hline NYHA class & III & $3(8 \%)$ \\
\cline { 2 - 3 } & IV & $37(92 \%)$ \\
\hline INTERMACS level & 1 & $3(8 \%)$ \\
\cline { 2 - 3 } & 2 & $15(38 \%)$ \\
\cline { 2 - 3 } & 3 & $14(36 \%)$ \\
\cline { 2 - 3 } & 4 & $6(15 \%)$ \\
\cline { 2 - 3 } & 5 & 0 \\
\cline { 2 - 3 } & 6 & $1(3 \%)$ \\
\hline Implanted device & & $7-25$ \\
\hline LVEF\% & & $17 \pm 4$ \\
\hline LVED [mm] & & $77 \pm 110$ \\
\hline NT-proBNP [pg/ml] & & $352-35000$ \\
& &
\end{tabular}

\section{Aim}

The aim of the study was to evaluate sarcoplasmic and interstitial myocardial fibrosis in patients with advanced heart failure requiring LVAD implantation, searching for mutual dependencies and formulation of cardiomyopathy grading, according to mentioned changes.

\section{Material and methods \\ Population study}

The study group consisted of 40 males with advanced heart failure, NYHA class III-IV, significantly decreased left ventricular ejection fraction, elevated left ventricle end-diastolic diameter and N-terminal pro-B-type natriuretic peptide (NT-proBNP) levels. Patients' age varied from 18 to 65 years old (mean: $48.1 \pm 10$ ). Among them, 12 patients suffered from ischemic cardiomyopathy (CM) and 28 from nonischemic CM. Nearly half of the group belonged to INTERMACS level 1-2, whereas the rest of the group revealed higher INTERMACS levels, 3-6.

The population characteristics of the patients are presented in Table I. All patients have undergone the implantation of an LVAD device: HeartWare Ventricular Assist Device (HeartWare, Inc. 14000 NW 57 $7^{\text {th }}$ Court Miami Lakes, FL 33014 USA). By the time of the analysis, 8 patients had received heart transplantation, 17 patients had died, whereas 16 were alive with a functioning LVAD. None of the patients had undergone LVAD explantation due to left ventricle recovery.

The control group consisted of 6 male heart donors ( $29 \pm 2.3$ years old), from whom the grafts were not suitable for transplantation due to spontaneous cardiac arrest. All hearts were macroscopically qualified as sound and utilized to harvest the valves and a pulmonary artery. There was no available cardiac history of these subjects. The group included 6 men with sound blood morphology.

\section{Tissue procurement}

Full-thickness apical tissue fragments harvested during LVAD implantation were fixed in $4 \%$ buffered formaldehyde solution for over $48 \mathrm{~h}$, then cut into $3 \mathrm{~mm}$ pieces and processed routinely to paraffin. Apical tissue was usually cut into 3-5 slices.

In the control group, heart excision took place presumably in the first $24 \mathrm{~h}$ after the death was revealed. After excision, the heart was rinsed with cold Ringer solution $\left(4^{\circ} \mathrm{C}\right)$, stored in cold, sterile conditions, and transported to a specialized 
laboratory. Before the histologic evaluation, each organ was carefully and thoroughly inspected to confirm its normal morphology. Apical fragments were fixed and processed in the same manner as described above. Additional evaluations, including microbiologic and serologic tests for exclusion of bacterial and/or viral infections or contamination, were performed routinely. In cases of the lack of gross and microscopic abnormalities, absent atherosclerotic lesions, and with a negative result in bacteriology and serology, the organ was classified as healthy. The cold ischemic time was $<4 \mathrm{~h}$.

\section{Histology}

Paraffin blocks containing tissue fragments were cut using a rotary microtome into $4 \mu \mathrm{m}$ slices and mounted onto microscopic slides. Slides were stained with H\&E for routine diagnosis, and with Masson trichrome with Fast Green FCF for evaluation of fibrosis and cardiomyocyte cytoplasm [4-6].

\section{Image acquisition}

At least 5 representative images were captured from each patient using a Nikon Eclipse microscope and a Canon EOS 500D digital camera at magnification 100 -fold, resolution $4762 \times 3168$ pixels. Slides with vast fibrosis, probably cicatrices, as well as with the presence of contraction bands, the predominance of adipose tissue or large vessels, were not accepted. Longitudinal cardiocyte sections were preferred.

\section{Digital image evaluation}

The editing and analysis of image and files (*.tif) were performed using Leica QWin v.3 software. Medium-sized vessels were deleted from an image. Then the tissue was divided into: a) fibrous tissue stained green with Masson trichrome, b) myofibrillolytic (MFL) cardiocytes with marked reduction of cytoplasmic myofibrils stained pale pink with Masson trichrome, c) cardiocytes with dense purple-red (non-MFL) sarcoplasm in Masson trichrome staining, d) blank space (Fig. 1).

Blank space was subtracted from the analyzed area, then each tissue compartment was measured [7]. Image area fraction (AF) of fibrous tissue, MFL, and non-MFL cardiocytes were calculated from the sum of the above-listed elements. The AF was presented as a percentage fraction.

\section{Formulation of cardiomyopathy grading scale}

The images from cases included in the study were printed for another histopathologic description, and the final descriptive diagnosis was formulated by two pathologists, experienced in myocardial pathology.

All cases were divided into four groups: a) control cases as cardiomyopathy grade 0 or no cardiomyopathy, b) cardiomyopathy grade 1 - mild, c) cardiomyopathy grade 2 moderate, d) cardiomyopathy grade 3 - advanced. All images were viewed in another double-blinded manner, and the final descriptive diagnosis was formulated by the same pathologists. Prevalent histology of each grade, assuming cardiocyte nuclear morphology, sarcoplasm, interstitium and others, is presented in Table II.

\section{Statistical analysis}

Data distribution was evaluated with the Shapiro-Wilk W test. Taking into account significant discrepancies with normal distribution nonparametric values such as minimum, maximum and median with quartiles were calculated and presented for both cohort and each grade. Grades were compared using the Mann-Whitney test. Correlations between fibrosis, myofibrillolysis and non-myofibrillolytic sarcoplasm with the grade of cardiomyopathy were estimated using the nonparametric Spearman $R$ test. Cohort measurements served to construct a mathematical model, clarifying the dependence between fibrosis and the two above-mentioned types of sarcoplasm. The linear regression model was calculated by a robust method, resistant for non-normal distribution and outliers. PAST software version 3.21 was used for the analytical procedure [8].

\section{Results}

In all studied CM/VAD patients, cardiomyopathic morphology was diagnosed histopathologically by two independent pathologists. Excluding myocarditis, there were no active or borderline inflammatory infiltrations in any case. In 18 cases there were inactive, sparse, and disperse infiltrations such as single lymphocytes, the number of which never exceeded 3 cells per high power view.

The results of the image measurements according to CM severity are presented in Table III. Cardiomyopathy grade 0 (none) included 6 control cases; all 44 images were representative and accepted for grade description.

Cardiomyopathy grade 1 (mild) included 10 patients and 86 images. Cardiomyopathy grade 2 (moderate) included 15 cases and 130 images. Cardiomyopathy grade 3 (severe) included 15 cases and 128 images. Image analysis values calculated for each group are presented in Table III. Neighboring groups were compared using the Mann-Whitney test, showing the significant probability for differences between the groups (Table III).

The correlation between cardiomyopathy grade and fibrosis was statistically significant (Spearman $R=0.64$, $p<0.00001)$. The strength of the correlation between cardiomyopathy grade and the area occupied by MFL cardiocytes was similar (Spearman $R=0.63, p<0.00001$ ), whereas the correlation between cardiomyopathy grade and non-MFL cardiocyte area fraction was remarkably high (Spearman $R=-0.95546, p<0.00001$ ).

The cohort study showed that nearly ten times higher fibrosis was observed in CM/VAD than in the control group. Moreover, MFL cardiomyocytes occupied a nearly five times larger image area in the CM-VAD group than in the control group. Non-MFL sarcoplasm was found predominantly in the control group, occupying an area twice as large as in cardiomyopathic cases. The linear regression model calculated by the robust method, more appropriate in biological models, showed significant dependencies between 


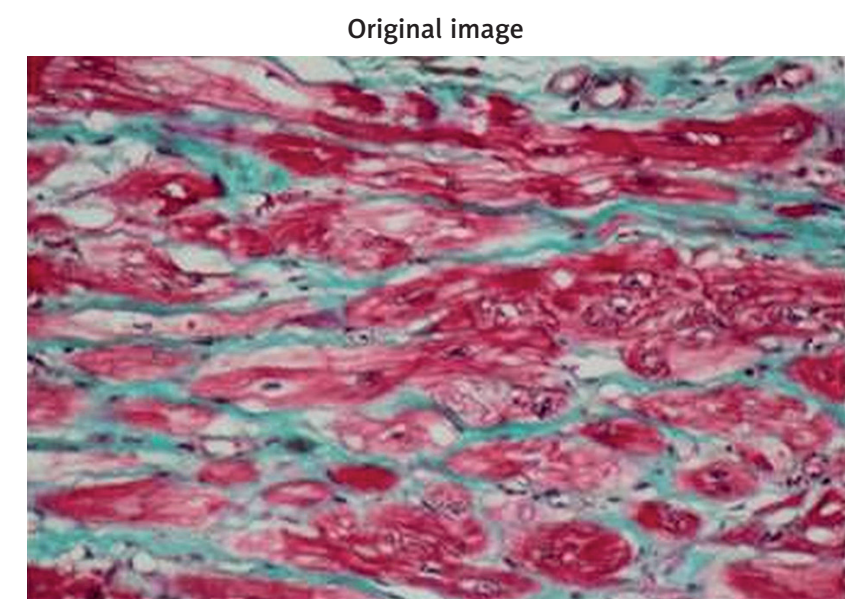

Image segmentation

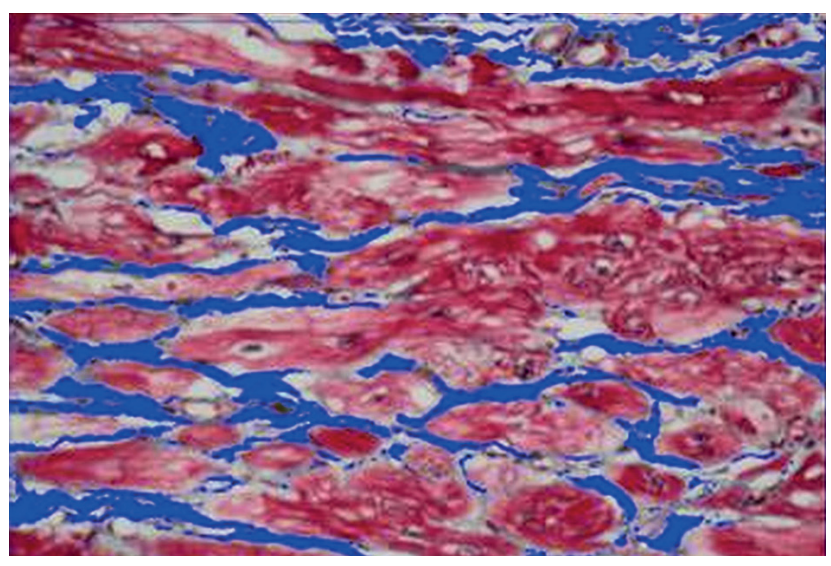

Fibrosis/collagen

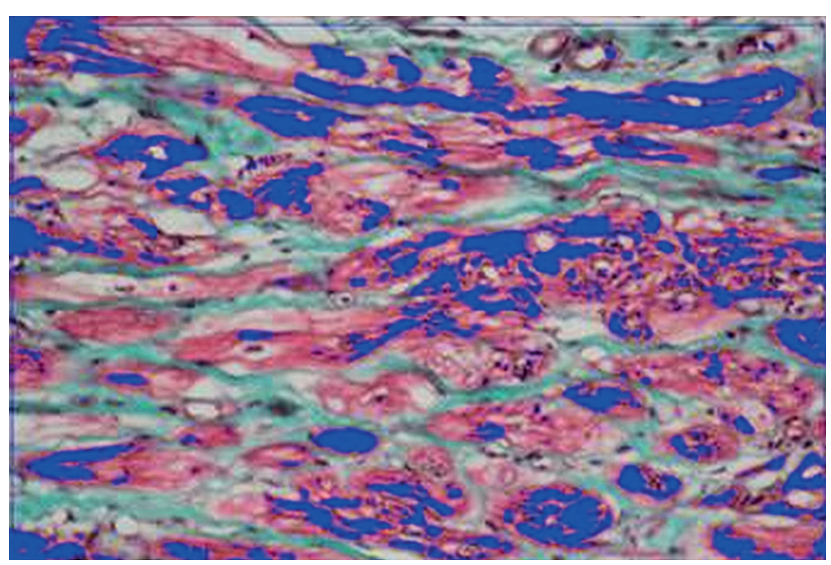

Non-myofibrillolytic cardiocytes Non-MFL

(normochromic sarcoplasm)

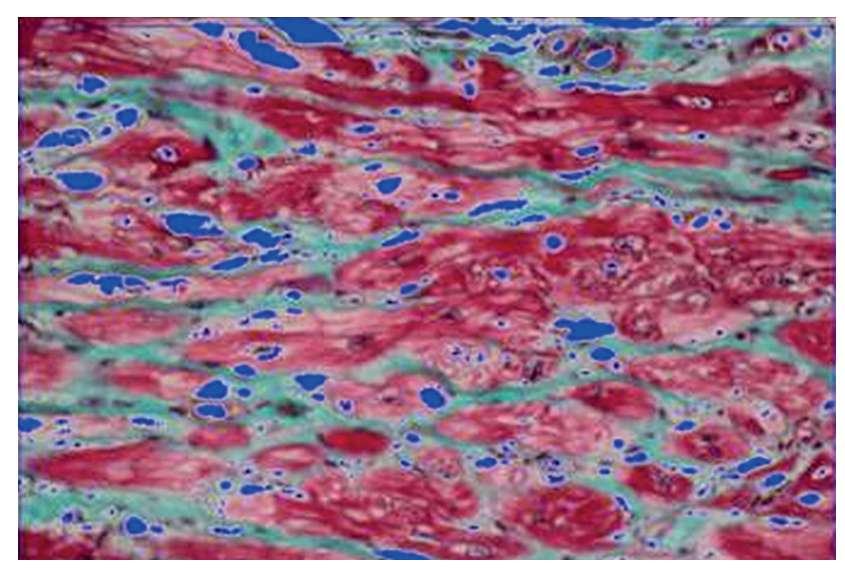

Blank space

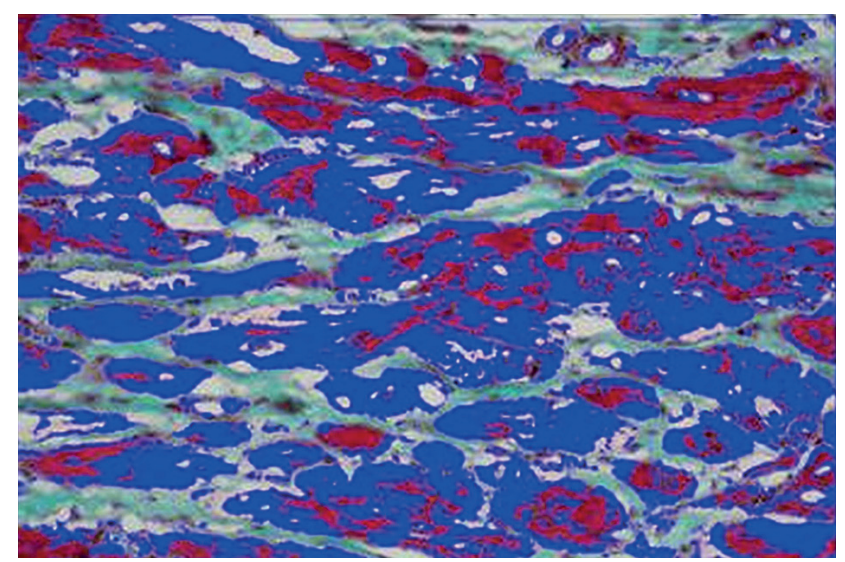

Myofibrillolytic cardiocytes MFL

(hypochromic sarcoplasm)

Fig. 1. Digital image editing and analysis. Original image stained with Masson trichrome (at the top) is segmented into four tissue compartments (below): green stained collagen, blank space, normal, non-myofibrillolytic cardiomyocytes stained red-purple and myofibrillolytic cardiomyocytes stained rose. Detected color was covered by blue mask

the fibrosis area fraction and two types of cardiocytes according to its sarcoplasm status (Table IV). CM/VAD group specimens demonstrated the progressive linear depletion of both MFL and non-MFL cardiomyocytes according to the progression of interstitial fibrosis, which is a strong suggestion that progressively vanishing cardiocytes were replaced by fibrous tissue. The control group specimens presented a nearly uniform and nonsignificant dependency between fibrosis and MFL cardiocytes, indicating the lack of active fibrosis replacement. The significant negative dependency between fibrosis and non-MFL sarcoplasm indicates the remodeling phenomenon. Diminishing area of non-MFL car- 
Table II. Histopathological grading of dilated cardiomyopathy

\begin{tabular}{|c|c|c|c|c|c|}
\hline Grade/name & "First look" diagnosis & Cardiocyte sarcoplasm & Cardiocyte nucleus & Interstitium & Others \\
\hline $\begin{array}{l}0 \\
\text { No cardiomyopathy }\end{array}$ & Normal myocardium & $\begin{array}{l}\text { Myofibrils poorly } \\
\text { visible, dense } \\
\text { sarcoplasm in almost } \\
\text { all cardiocytes }\end{array}$ & $\begin{array}{l}\text { Rather uniform } \\
\text { oval or rounded. } \\
\text { Chromatin uniform } \\
\text { and delicately } \\
\text { granular }\end{array}$ & $\begin{array}{l}\text { Poorly visible, } \\
\text { reduced to few } \\
\text { thin collagen } \\
\text { fibers between } \\
\text { cardiocytes. Single } \\
\text { fibroblasts }\end{array}$ & $\begin{array}{l}\text { Single lymphocytes } \\
\text { and/or other } \\
\text { connective tissue } \\
\text { cells inside } \\
\text { interstitial network } \\
\text { at the proximity } \\
\text { of vessels }\end{array}$ \\
\hline I & $\begin{array}{l}\text { Slight hypertrophy } \\
\text { and patchy fibrosis. } \\
\text { Practically uniform } \\
\text { staining. Possible } \\
\text { cardiomyopathy }\end{array}$ & $\begin{array}{l}\text { Infrequent distension } \\
\text { and attenuation } \\
\text { of cardiocytes. } \\
\text { Myofibrillolysis, } \\
\text { premyocytolysis } \\
\text { frequent. Unchanged } \\
\text { cardiocytes not less } \\
\text { than 30\% }\end{array}$ & $\begin{array}{l}\text { Some cardiocyte } \\
\text { nuclei } \\
\text { hyperchromatic, } \\
\text { hypertrophied, } \\
\text { enlarged }\end{array}$ & $\begin{array}{l}\text { Fibrosis not } \\
\text { exceeding nearly } \\
10 \% \text { of the tissue. } \\
\text { Subtle collagen } \\
\text { network and/or } \\
\text { single scars. } \\
\text { Non-numerous } \\
\text { fibroblasts }\end{array}$ & $\begin{array}{l}\text { Lymphocytes } \\
\text { sporadically seen } \\
\text { inside interstitial } \\
\text { network, with } \\
\text { no contact with } \\
\text { cardiocytes. } \\
\text { No active } \\
\text { inflammatory foci }\end{array}$ \\
\hline Moderate & $\begin{array}{l}\text { Image could suggest } \\
\text { fibrosis. Tissue } \\
\text { rarefied. Probable } \\
\text { cardiomyopathy }\end{array}$ & $\begin{array}{l}\text { Cardiocytes arranged } \\
\text { loosely. Cardiocyte } \\
\text { changes as above, } \\
\text { but more intense. } \\
\text { Unchanged cardiocytes } \\
\text { below } 30 \%\end{array}$ & $\begin{array}{c}\text { Cardiocyte } \\
\text { nuclei enlarged, } \\
\text { hyperchromatic, } \\
\text { rounded or angular }\end{array}$ & $\begin{array}{c}\text { Collagen as } \\
\text { network or scars, } \\
\text { forms groups of } \\
\text { cardiocytes. Variable } \\
\text { number } \\
\text { of fibroblasts }\end{array}$ & $\begin{array}{l}\text { As above. Pericytes } \\
\text { and single mast } \\
\text { cells could suggest } \\
\text { inflammation }\end{array}$ \\
\hline $\begin{array}{l}\text { III } \\
\text { Severe }\end{array}$ & $\begin{array}{c}\text { Fibrosis with rare } \\
\text { bright and enlarged } \\
\text { cardiocytes. } \\
\text { Tissue rarefied. } \\
\text { Cardiomyopathy }\end{array}$ & $\begin{array}{l}\text { Loose structure except } \\
\text { scars. Myofibrillolysis } \\
\text { and premyocytolysis } \\
\text { as above. Unchanged } \\
\text { cardiocytes rare }\end{array}$ & $\begin{array}{l}\text { As above, also } \\
\text { vesicular nuclei } \\
\text { with marginated } \\
\text { chromatin, and } \\
\text { bizarre dense dark } \\
\text { nuclei not rare }\end{array}$ & $\begin{array}{l}\text { Dense and loose } \\
\text { collagen surrounds } \\
\text { cardiocytes. }\end{array}$ & $\begin{array}{l}\text { As above. Visually } \\
\text { increased number } \\
\text { of capillaries. Focally } \\
\text { subendocardial } \\
\text { vessels }\end{array}$ \\
\hline
\end{tabular}

diocytes is significantly associated with the progression of MFL cardiocytes in both groups, CM/VAD and control, but in the control group, the process is restricted to a small part of non-MFL sarcoplasm, whereas in the CM/VAD group the extent of this process was more intense.

Images from each group were printed for another histopathologic description. The final diagnosis was formulated by two independent pathologists. Prevalent morphologic changes assuming nuclear morphology, sarcoplasm, and interstitium are proposed in Table II.

\section{Discussion}

Histopathological similarities between multiple, nonspecific cardiomyopathies of various etiology was a major cause of setting endomyocardial biopsy as an adjunctive diagnostic tool and a way for harvesting myocardial samples for genetic or molecular tests [9]. Histopathological findings reported by Strecker et al. [10] in end-stage heart failure also showed no difference in apical histopathology between seven different cardiomyopathies, valvular diseases and congenital heart defects, although numerous specimens of much more extensive tissue than in endomyocardial biopsy provided more detailed information.

In general, the cohort findings described here did not differ from those mentioned above. Contrary to biopsies, a large amount of tissue allowed us not only to establish the final diagnosis but also to conduct measurements. The study described by Daunoravicius et al. [11] assessed myocardial fibrosis in 38 endomyocardial biopsies from cases with postinflammatory dilated cardiomyopathy (DCM) using a stereology grid, colocalization and Genie software. Median fibrosis area fraction was from $8.70 \%$ estimated stereologically to the maximum of $11.12 \%$ using the colocalization method. These results are similar to those reported by us in grade $1 \mathrm{CM}$, but it should be pointed out that endomyocardial biopsies were harvested from the right side intra ventricular septum (IVS), whereas the apical core presented more different images and more advanced fibrosis. The majority of earlier studies, including Olsen's classical publications [4-6, 10, 12], indicated the presence of cardiocytes pathology and fibrosis in cardiomyopathic hearts. Interstitial fibrosis of various intensity draws apart cardiocytes dividing these cells, forming a collagen network or scars. Cardiocyte pathology presents a variety of changes: focal premyocytolysis and myocytolysis, sarcoplasmic distension, attenuation and/or degeneration with rarefied myofilaments as a result of myofibrillolysis (cardiomyocytes with this pathology were marked as "MFL cardiocytes" for the purpose of this study). Our previous findings [12] indicated broad variability in fibrosis and cardiocyte hypertrophy parameters in cardiomyopathy; thus, we decided not only to construct a mathematical model of dependences between fibrosis and cardiocytes but also to evaluate cardiocytes as "healthy" - non-MFL and "damaged" - showing MFL (Table V). The loss of cardiocyte myofibrils in response to injury or disease was mentioned in a few papers as characteristic for cardiomyopathies, or overtaking the myocytolysis [13-16], whereas the amount of remnant cardiocytes has never been evaluated. 
Table III. Image analysis results from CM/VAD and control/comparative group, according to cardiomyopathy grades

\begin{tabular}{|c|c|c|c|c|}
\hline Grades & $\begin{array}{l}\text { Cardiomyopathy grade } 0 \\
\text { (no cardiomyopathy) }\end{array}$ & $\begin{array}{l}\text { Cardiomyopathy grade } 1 \\
\text { (mild cardiomyopathy) }\end{array}$ & $\begin{array}{c}\text { Cardiomyopathy grade } 2 \\
\text { (moderate } \\
\text { cardiomyopathy) }\end{array}$ & $\begin{array}{c}\text { Cardiomyopathy grade } 3 \\
\text { (advanced } \\
\text { cardiomyopathy) }\end{array}$ \\
\hline \multicolumn{5}{|c|}{ Fibrosis area fraction (\%): } \\
\hline Range (min.-max.) & $0.3-13$ & $1-47$ & $1-59$ & $1-75$ \\
\hline Median & 2 & 10 & 19 & 25 \\
\hline Upper-lower quartile & $1-4$ & $6-16$ & $11-27$ & $17-38$ \\
\hline$P$ probability & \multicolumn{2}{|c|}{$<0.0001$} & \multicolumn{2}{|c|}{$<0.0001$} \\
\hline Mann-Whitney test & - & $<0$. & 001 & - \\
\hline \multicolumn{5}{|c|}{ MFL cardiocyte area fraction: } \\
\hline Range (min.-max.) & $1-24$ & $9-58$ & $8-69$ & $13-86$ \\
\hline Median & 8 & 40 & 49 & 57 \\
\hline Upper-lower quartile & $5-14$ & $32-46$ & $41-56$ & $43-67$ \\
\hline$P$ probability & \multicolumn{2}{|c|}{$<0.0001$} & \multicolumn{2}{|c|}{$<0.0001$} \\
\hline Mann-Whitney test & - & & & - \\
\hline \multicolumn{5}{|c|}{ Non-MFL cardiocyte area fraction: } \\
\hline Range (min.-max.) & $71-97$ & $4-79$ & $25-40$ & $4-25$ \\
\hline Median & 89 & 48 & 33 & 17 \\
\hline Upper-lower quartile & $82-92$ & $43-52$ & $29-36$ & $12-21$ \\
\hline$P$ probability & \multicolumn{2}{|c|}{$<0.0001$} & \multicolumn{2}{|c|}{$<0.0001$} \\
\hline Mann-Whitney test & - & $<0$. & 001 & - \\
\hline
\end{tabular}

Table IV. The dependence of fibrosis area fraction on cardiomyopathy intensity - descriptive statistics and Mann-Whitney pairwise tests

\begin{tabular}{lccc} 
Fibrosis area fraction & Cardiomyopathy slight grade & Cardiomyopathy moderate grade & Cardiomyopathy severe grade \\
No. of measurements & 85 & 126 & 133 \\
\hline Min.-max. & $0.19-0.74$ & $0.13-0.80$ & $0.08-0.86$ \\
\hline Mean \pm SD & $0.44 \pm 0.12$ & $0.49 \pm 0.15$ & $0.50 \pm 0.15$ \\
\hline Median & 0.43 & 0.49 & 0.50
\end{tabular}

Mann-Whitney pairwise tests Cardiomyopathy slight grade Cardiomyopathy moderate grade Cardiomyopathy severe grade

\begin{tabular}{lccc} 
Cardiomyopathy slight grade & - & 0.01 & 0.003 \\
\hline Cardiomyopathy moderate grade & 0.01 & - & NS \\
\hline Cardiomyopathy severe grade & 0.003 & NS & -
\end{tabular}

Table V. Linear regression robust model of relations between interstitial fibrosis area fraction and with sarcoplasm status according to amount of myofibrils

\begin{tabular}{|c|c|c|c|c|c|c|}
\hline \multirow[t]{3}{*}{ Variable } & \multicolumn{6}{|c|}{ Robust linear regression between } \\
\hline & \multicolumn{2}{|c|}{$\begin{array}{c}\text { Fibrosis area fraction } \\
\text { and myofibrillolytic sarcoplasm } \\
\text { area fraction }\end{array}$} & \multicolumn{2}{|c|}{$\begin{array}{c}\text { Fibrosis area fraction } \\
\text { and non-myofibrillolytic sarcoplasm } \\
\text { area fraction }\end{array}$} & \multicolumn{2}{|c|}{$\begin{array}{l}\text { Non-myofibrillolytic sarcoplasm } \\
\text { and myofibrillolytic sarcoplasm } \\
\text { area fraction }\end{array}$} \\
\hline & CM/VAD & $\begin{array}{c}\text { Control/ } \\
\text { comparative }\end{array}$ & CM/VAD & $\begin{array}{c}\text { Control/ } \\
\text { comparative }\end{array}$ & CM/VAD & $\begin{array}{c}\text { Control/ } \\
\text { comparative }\end{array}$ \\
\hline \multicolumn{7}{|c|}{ Robust linear regression model: } \\
\hline Slope $a$ & -0.510 & -0.061 & -0.491 & -1.008 & -0.641 & -0.855 \\
\hline Intercept $b$ & 58.209 & 6.7778 & 41.506 & 93.782 & 71.887 & 84.832 \\
\hline Pearson $r$ & -0.476 & 0.2088 & -0.470 & -0.566 & -0.551 & -0.924 \\
\hline $\begin{array}{l}\text { Determination } \\
\text { coefficient } r^{2}\end{array}$ & 0.226 & 0.043 & 0.221 & 0.320 & 0.303 & 0.850 \\
\hline Probability $p$ & $<0.0001$ & $0.17 \mathrm{NS}$ & $<0.0001$ & $<0.0001$ & $<0.0001$ & $<0.0001$ \\
\hline
\end{tabular}


The observed extent of fibrosis varied greatly in the CM/VAD group from slight to intense, ranging from $1 \%$ to $75 \%$ of the area. Based on some data from the literature, we hypothesize that the growing intensity of the assessed cardiomyopathy may correlate with the clinical status of patients [17]. Interstitial fibrosis, morphometrically evaluated according to the proposed cardiomyopathy grading, showed a progressive increase in each grade, starting from a few percent in grade 0 or the control group and finally reaching nearly a half of the myocardium in severe cardiomyopathy (Table III). Moreover, grades statistically differed from each other. It should be emphasized that the grading scale was established based only on general histopathology, whereas morphometry confirms these observations.

Clinically proven myocardial insufficiency should be logically correlated not only with progressive myocardial fibrosis but also with the loss of cardiocytes or its sarcoplasmic contractile elements - myofibrils during myofibrillolytic processes [18]. The amount of myofibrillolytic cardiocytes according to the proposed grading scale was similar in grade 1 and 2, showing a progressive decrease, and significant in grade 3 . These phenomena - progressive fibrosis and a regressive amount of injured cardiocytes - clearly suggest the dynamic process of replacement fibrosis. Moreover, a documented loss of non-MFL cardiocytes suggests a progressive loss of contractile function. It should be emphasized that the percentage of MFL and non-MFL cardiocytes correlated linearly with interstitial fibrosis in cohort analysis using robust linear regression only in the CM/VAD group.

It should be pointed out that attempts at quantification of end-stage heart failure in explanted hearts had already been made by Segura et al. [19], and Ottaviani et al. [20]. They proposed the grading of fibrosis, hypertrophy and myocytolysis, but missed the grading scale or morphometry. Besides, the results suggested by the authors mentioned above indicated that cardiocyte hypertrophy counterbalances the negative effects of fibrosis and myocytolysis, whereas they did not take into account semiquantitative or quantitative evaluation of the number of unchanged cardiocytes, which play a crucial role in myocardial recovery. A different point of view was presented by Rivello et al. [21], who determined a normalizing ploidy index and a decrease of hypertrophied cardiocyte dimensions as reversible phenomena in two patients with LVAD. Muthiah et al. [22] demonstrated histological recovery after LVAD implantation as the regression of cardiocyte hypertrophy. Histopathological recovery of myocardium after LVAD unloading revealed some interesting facts, suggesting the regeneration of myocardium through the proliferation of cardiocytes estimating phosphorylated histone 3; however, histopathology was not presented [23]. Another study indicated the role of adjunctive pharmacotherapy aside from the LVAD unloading [24]. On the other hand, after LVAD implantation the increase of interstitial fibrosis and distension of cardiocytes were observed; a comparative specimen was harvested during LVAD implantation together with another, excised from the LV free wall [25]. Marinescu et al. [26] suggested that reverse remodeling could be linked with proinflammatory profile in advanced heart failure patients.

According to the aforementioned articles, it would be valuable to assess the apical core in a routine manner and with the unified grading scale; otherwise, it might be impossible to assume that LVAD implantation took place at the same cardiomyopathy structural advancement. The limitation of our study may be the relatively small study group.

\section{Conclusions}

The correlation between unchanged cardiocytes, fibrosis, and myofibrillolytic cells suggests that a real measurement of the advancement of cardiomyopathy belongs to the remnant part of healthy cardiac cells rather than degeneration and postnecrotic phenomena such as fibrosis.

\section{Acknowledgments}

The study was supported by Silesian Medical University grant no. KNW-1-142/N/6/K.

\section{Disclosure}

The authors report no conflict of interest.

\section{References}

1. Escher F, Lassner D, Kühl U, Gross U, Westermann D, Poller W, Skurk C, Weitmann K, Hoffmann W, Tschöpe C, Schultheiss HP. Analysis of endomyocardial biopsies in suspected myocarditis - diagnostic value of left versus right ventricular biopsy. Int J Cardiol 2014; 177: 76-78.

2. Chimenti C, Frustaci A. Contribution and risks of left ventricular endomyocardial biopsy in patients with cardiomyopathies: a retrospective study over a 28-year period. Circulation 2013; 128: 1531-1541.

3. Cazes A, Duong Van Huyen JP, Fornes P, Amrein C, Guillemain R, Grinda JM, Bruneval $P$. Mechanical ventricular assistance in heart failure: pathology of the cardiac apex removed during device implantation. Cardiovasc Pathol 2010; 19: 112-16.

4. Davies MJ. The cardiomyopathies: an overwiew. Heart 2000; 83: 469-474.

5. Radu RI, Bold A, Pop OT, Mălăescu DG, Gheorghişor I, Mogoantă L. Histological and immunohistochemical changes of the myocardium in dilated cardiomyopathy. Rom J Morphol Embryol 2012; 53: 269-275.

6. Ishibashi-Ueda H, Matsuyama TA, Ohta-Ogo K, Ikeda Y. Significance and value of endomyocardial biopsy based on our own experience. Circ J 2017; 81: 417-426.

7. Vogel B, Siebert H, Hofmann U, Frantz S. Determination of collagen content within picrosirius red stained paraffin-embedded tissue sections using fluorescence microscopy. MethodsX 2015; 21: 124-134.

8. Hammer $\varnothing$, Harper DAT, Ryan PD. PAST: paleontological statistics software package for education and data analysis. Palaeontologia Electronica 2001; 4: $1-9$.

9. Pinto YM, Elliott PM, Arbustini E, Adler Y, Anastasakis A, Böhm M, Duboc D, Gimeno J, de Groote P, Imazio M, Heymans S, Klingel K, Komajda M, Limongelli G, Linhart A, Mogensen J, Moon J, Pieper PG, Seferovic PM, Schueler S, Zamorano JL, Caforio AL, Charron P. Proposal for a revised definition of dilated cardiomyopathy, hypokinetic non-dilated cardiomyopathy, and its implications for clinical practice: a position statement of the ESC working group on myocardial and pericardial diseases. Eur Heart J 2016; 37: 1850-1858.

10. Strecker T, Rösch J, Weyand M, Agaimy A. Pathological findings in cardiac apex removed during implantation of left ventricular assist devices (LVAD) are non-specific: 13-year-experience at a German Heart Center. Int J Clin Exp Pathol 2014; 7: 5549-5556.

11. Daunoravicius D, Bessusparis J, Zurauskas E, Laurinaviciene A, Bironaite D, Pankuweit S, Plancoulaine B, Herlin P, Bogomolovas J, Grabauskiene V, Lau rinavicius A. Quantification of myocardial fibrosis by digital image analysis and interactive stereology. Diagn Pathol 2014; 9: 114-124. 
12. Nozyński J, Zakliczyński M, Konecka-Mrówka D, Zegleń S, Przybylski R, Zembala M, Lange D, Zembala-Nozyńska E, Mecik-Kronenberg T, Dabrówka K. Differences in antiapoptotic, proliferative activities and morphometry in dilated and ischemic cardiomyopathy: study of hearts explanted from transplant recipients. Transplant Proc 2009; 41: 3171-3178.

13. Frustaci A, Ciccosanti F, Chimenti C, Nardacci R, Corazzari M, Verardo R, Ippolito G, Petrosillo N, Fimia GM, Piacentini M. Histological and proteomic profile of diabetic versus non-diabetic dilated cardiomyopathy. Int J Cardiol 2016; 203: 282-289.

14. Turillazzi E, Baroldi G, Silver MD, Parolini M, Pomara C, Fineschi V. A systematic study of a myocardial lesion: colliquative myocytolysis. Int J Cardiol 2005; 104: 152-157.

15. Baroldi G, Bigi R, Cortigiani L. Ultrasound imaging versus morphomathology in cardiovascular diseases: the heart failure. Cardiovasc Ultrasound 2007; 5: 5.

16. Cove-Smith L, Woodhouse N, Hargreaves A, Kirk J, Smith S, Price SA, Galvin M, Betts CJ, Brocklehurst S, Backen A, Radford J, Linton K, Roberts RA, Schmitt M, Dive C, Tugwood JD, Hockings PD, Mellor HR. An integrated characterization of serological, pathological, and functional events in doxorubicin-induced cardiotoxicity. Toxicol Sci 2014; 140: 3-15.

17. Gulati A, Jabbour A, Ismail TF, Guha K, Khwaja J, Raza S, Morarji K, Brown TD, Ismail NA, Dweck MR, Di Pietro E, Roughton M, Wage R, Daryani Y, O'Hanlon R, Sheppard MN, Alpendurada F, Lyon AR, Cook SA, Cowie MR, Assomull RG, Pennell DJ, Prasad SK. Association of fibrosis with mortality and sudden cardiac death in patients with nonischemic dilated cardiomyopathy. JAMA 2013; 309: 896-908.

18. Glashan CA, Androulakis AFA, Tao Q, Glashan RN, Wisse LJ, Ebert M, de Ruiter MC, van Meer BJ, Brouwer C, Dekkers OM, Pijnappels DA, de Bakker JMT, de Riva M, Piers SRD, Zeppenfeld K. Whole human heart histology to validate electroanatomical voltage mapping in patients with non-ischaemic cardiomyopathy and ventricular tachycardia. Eur Heart J 2018; 39: 2867-2875.
19. Segura AM, Frazier OH, Demirozu Z, Buja LM. Histopathologic correlates of myocardial improvement in patients supported by a left ventricular assist device. Cardiovasc Pathol 2011; 20: 139-145.

20. Ottaviani G, Radovancevic R, Kar B, Gregoric I, Buja LM. Pathological assessment of end-stage heart failure in explanted hearts in correlation with hemodynamics in patients undergoing orthotopic heart transplantation. Cardiovasc Pathol 2015; 24: 283-289.

21. Rivello HG, Meckert PC, Vigliano C, Favaloro R, Laguens RP. Cardiac myocyte nuclear size and ploidy status decrease after mechanical support. Cardiovasc Pathol 2001; 10: 53-57.

22. Muthiah K, Humphreys DT, Robson D, Dhital K, Spratt P, Jansz P, Macdonald PS, Hayward CS. Longitudinal structural, functional, and cellular myocardial alterations with chronic centrifugal continuous-flow left ventricular assist device support. J Heart Lung Transplant 2017; 36: 722-731.

23. Canesco DC, Kimura W, Garg S, Mukherjee S, Bhattacharya S, Abdisalaam S, Das S, Asaithamby A, Mammen PP, Sadek HA. Human ventricular unloading induces cardiomyocyte proliferation. J Am Coll Cardiol 2015; 65: 892-900.

24. Birks EJ, George RS, Hedger M, Bahrami T, Wilton P, Bowles CT, Webb C, Bougard R, Amrani M, Yacoub MH, Dreyfus G, Khaghani A. Reversal of severe heart failure with a continuous-flow left ventricular assist device and pharmacological therapy: a prospective study. Circulation 2011; 123: 381-390.

25. Lok S, Nous FM, van Kuik J, van der Weide P, Winkens B, Kemperman H, Huisman A, Lahpor JR, de Weger RA, de Jonge N. Myocardial fibrosis and pro-fibrotic markers in end-stage heart failure patients during continuous-flow left ventricular assist device support. Eur J Cardiothorac Surg 2015; 48: 407-415.

26. Marinescu KK, Uriel N, Mann DL, Burkhoff D. Left ventricular assist deviceinduced reverse remodeling: it's not just about myocardial recovery. Expert Rev Med Devices 2017; 14: 15-26. 